КИЇВСЬКИЙ НАЦІОНААЬНИЙ УНІВЕРСИТЕТ IMЕНІ ТАРАСА ШЕВЧЕНКА

TARAS SHEVCHENKO NATIONAL UNIVERSITY OF KYIV
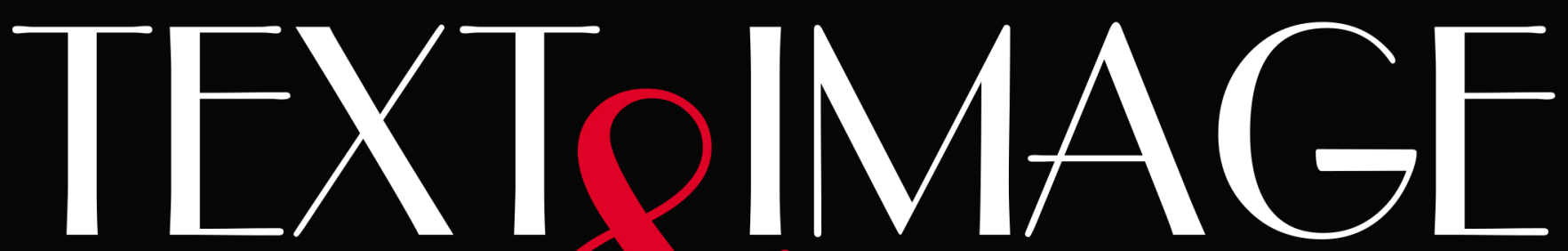

ESSENTIAL PROBLEMS IN ART HISTORY

$20212(12)$

TEKCT I OBPA3:

актуальні проблеми історії мистецтва 


\title{
TEXT AND IMAGE: ESSENTIAL PROBLEMS IN ART HISTORY
}

\author{
scientific electronic journal
}

\section{1, volume 2 (12)}

Founder: Taras Shevchenko National University of Kyiv

Year of foundation: 2016

Field of study: History

Language of publishing: Ukrainian, English, German, Polish, Russian, French.

Frequency: twice a year

Editorial board:

Gennadii Kazakevych, Dr. of Sc., Professor, Taras Shevchenko National University of Kyiv (Ukraine) - editor-in-chief Petro Kotliarov , Dr. of Sc., Associate professor, Taras Shevchenko National University of Kyiv (Ukraine) - deputy editor-in-chief

Oleksandr Okhrimenko, PhD, Taras Shevchenko National University of Kyiv (Ukraine) - managing editor Iryna Adamska, PhD, Taras Shevchenko National University of Kyiv (Ukraine) - executive editor Stefaniia Demchuk, PhD, Taras Shevchenko National University of Kyiv (Ukraine) - executive editor Anna Kaluher, MA, Taras Shevchenko National University of Kyiv (Ukraine) - editor of Art Criticism section Natalia Burdo, PhD, Institute of Archaeology, National Academy of Sciences in Ukraine (Ukraine) Volodymyr Dyatlov , Dr. of Sc., Professor, Taras Shevchenko National Pedagogical University of Chernihiv (Ukraine) Maxim Fomin , PhD, Senior lecturer, University of Ulster (United Kingdom of Great Britain and Northern Ireland) Nathalie-Cécile Ginoux, PhD, Maître de conférences en art et archéologie des mondes celtes, Université ParisSorbonne (Paris IV) (France)

Rostyslav Konta , Dr. of Sc., Professor, Taras Shevchenko National University of Kyiv (Ukraine) Oleg Mashevskiy, Dr. of Sc., Professor, Taras Shevchenko National University of Kyiv (Ukraine) Pedro Reyes Moya-Maleno, PhD, Universidad Complutense de Madrid (Spain) Antoniy Moysey , Dr. of Sc., Professor, Bukovinian State Medical University (Ukraine) Aneta Pawłowska, Dr. Hab., Professor, Instytut Historii Sztuki Uniwersytetu Łódzkiego (Polska) Andrii Puchkov, Dr. of Sc. Professor, Modern Arts Research Institute (Ukraine)

Matthew Rampley, PhD, independent scientist-researcher, Faculty of Arts, Masaryk University (Czech Republic) Sergei Ryzhov, PhD, Associate professor, Taras Shevchenko National University of Kyiv (Ukraine) Ihor Sribnyak, Dr. of Sc., Professor, Borys Grinchenko Kyiv University (Ukraine)

Arno Strohmeyer, PhD, Professor, University of Salzburg (Austria)

Oleksandr Symonenko, Dr. of Sc., Senior Researcher, Institute of Archaeology, National Academy of Sciences in Ukraine (Ukraine)

Mykhailo Videiko, Dr. of Sc., Senior Researcher, Borys Grinchenko Kyiv University (Ukraine)

Daqing Yang, PhD, Associate Professor, The George Washington University (U.S.A.)

Editorial board address: 01601, Ukraine, Kyiv, Str. Volodymyrska, 60, Taras Shevchenko National University of Kyiv, Faculty of History, Art History department; tel. +380442393407; e-mail: arthistory@univ.net.ua

The journal is published by the authority of the Academic Senate of the Taras Shevchenko National University. Decision №17. June, 29, 2016.

The journal is included in the Ukrainian list of specialized scientific publications (Ministry of Education and Science of Ukraine, decision №374. March, 13, 2017)

\section{ISSN 2519-4801}

Image on the cover: Stuttgart Psalter, Württembergische Landesbibliothek, Cod.bibl.fol. 23

DOI: $10.17721 / 2519-4801.2021 .2$ 


\section{MICT \\ CONTENTS}

\section{ANCIENT, MEDIEVAL AND EARLY MODERN ART}

Зелінський А. Морські мозаїки з Тмуїсу, цариця Береніка II та мендеські пахощі: новий погляд на стару проблему

Zelinskyi A. Sea Mosaics from Thmouis, Queen Berenice II and Mendesian Aromas: A New Look at the Old Problem.

Друздєв О. Біблійні та місіонерські сюжети в оздобленні Гарнізонного храму святих апостолів Петра і Павла у Львові (колишній костел єзуїтів)

Druzdiev O. Biblical and missionary plots in the decoration of Saints Peter \& Paul Garrison church (former Jesuit church).

Гуцул В. Проторицарство? Франкська армована кіннота VIII - X століття у візуальних джерелах Hutsul V. Protochivalry? Frankish Armored Cavalry in $8^{\text {th }}-10^{\text {th }}$ Centuries as They Depicted in Visual Sources

Demchuk S. Late Gothic (Antwerp) Mannerism: Its Origins, Nature And Decline (A Review of the Literature)

Демчук С. Пізньоготичний (Антверпенський) маньєризм: його витоки, характер та зникнення (нарис історіографії).

\section{MODERN AND CONTEMPORARY ART}

Адамська І. Візуальні матеріали журналу «Шлях до здоров'я» як інструмент антитуберкульозної кампанії в УСРР (1920-ті роки): просвіта і пропаганда

Adamska I. Visual materials of the journal «Shliakh do zdorovia» («Path to Health») as a tool of an anti-tuberculosis campaign in the Ukrainian SSR (in the 1920s):

Education and propaganda.

Зубар М., Магдич О. Спроба створення нових музейних наративів у виставковому дослідницькому проєкті «Шевченко мовою міста» Zubar M., Mahdych $\mathbf{O}$. An attempt of creating new museum narratives by the example of the exhibition project «Shevchenko by the urban tongue».

\section{ART CRITICISM}

Каленська І. Концепція кориди в живописному циклі «Ole!» Леся Подерв'янського

Kalenska I. The concept of a bullfight in the painting cycle «Ole!» by Les Podervianskyi. 
DOI: $10.17721 / 2519-4801.2021 .2 .06$

\title{
СПРОБА СТВОРЕННЯ НОВИХ МУЗЕЙНИХ НАРАТИВІВ У ВИСТАВКОВОМУ ДОСЛІДНИЦЬКОМУ ПРОЄКТІ «ШЕВЧЕНКО МОВОЮ МІСТА»
}

\author{
Михайло Зубар, Олег Магдич
}

\section{An attempt of creating new museum narratives by the example of the exhibition project "Shevchenko by the urban tongue»}

\section{Mykhailo Zubar, Oleh Mahdych}

Taras Shevchenko is one of the most researched and discussed figures in Ukrainian society. In each historical period receptions and assessments around Shevchenko' personality differentiates, depending on the public circumstances or prevailing trends in humanitarian discourse. These perceptions swayed between positive and critical judgment. Authors identified several key perceptions of Shevchenko in Ukrainian public space, for instance, "national hero", "father of the nation", "poet», "revolutionary democrat». In their opinion, modern Ukraine still faces the search for Shevchenko' new image. New forms of public honour (commemoration) are being developed, including through museum exhibition projects. Authors also analyze the significance of the museum narrative expositions and exhibitions for the creation of new public images, giving the example of the exhibition project "Shevchenko by the urban tongue», which took place in the Taras Shevchenko national museum from November 4th to January 31th in 2021. Curators attempted to explore how personal experience in the city changed due to the process of urbanization from the $X I X-t h$ century and how the urban space influenced the shaping of the Taras Shevchenko figure. Specifically, in the XIX-th century, cities ultimately transformed into an environment, which created trends, emphases of the global public development that influenced Shevchenko, since exactly in the city he gained domestic freedom, profession and widened his social circle. The city gave him a sense of understanding of the culture, its influence and importance not only for consumer purposes or acceptance but also for the creation of new meanings. According to the authors, this approach allows us to better understand the significance of Taras Shevchenko, his connection to modern Ukrainian realities and world context.

Key words: Taras Shevchenko, narrative exposition, commemoration, urbanization, Taras Shevchenko national museum, exhibition.

Тарас Шевченко - одна 3 найбільш досліджуваних постатей в українській гуманітаристиці. Корпус наукових розвідок про нього налічує понад тисячі публікацій (Вівсяна 2012, с. 75). Деякі дослідники інколи навіть називають шевченкознавство окремою галуззю, хоч логіка такого підходу не $є$ очевидною. Тарас Шевченко став своєрідним феноменом української гуманітаристики. Не в останню чергу це пов'язано з тим фактом, що рецепція і оцінка Шевченка в різний час та в умовах існування різних соціальних моделей коливалася від вкрай позитивної («батько нації», «пророк» (Пріцак 1993, с. 33) до критичної («спалити «Кобзар» (Семенко 1998, с. 61-62)). Як правило, вони залежали від суспільної, а часто й політичної ситуації, трендів у гуманітарному дискурсі, а самі дослідження його 
особистості й діяльності були прив'язані до різних історико-культурних контекстів. Саме це й вплинуло на специфіку вивчення постаті Тараса Шевченка в різні періоди й формування доволі специфічних та різноманітних наукових дискурсів навколо дослідження діяльності поета та художника і пов'язаних з ним тем.

Спочатку на процес вивчення феномена Тараса Шевченка впливав український національний дискурс, що почав формуватися у другій половині XIX - першій половині XX століття і потребував ідеальних особистостей-героїв. Значний вплив на нього мав модернізм (у різних варіантах, зокрема, радянському) з його критичним відношенням до «народної культури» і потреби наукової інтерпретації історичних діячів.

Сьогодні дослідників Шевченка можна розділити на кілька груп: пафосні співці, які всіляко вихваляють його значення (фактично, адепти і популяризатори його культу), абсолютні критики, які відкидають будь-які прославляння поета і старанно розвінчують його культ і канон; а також вчені, які намагаються об'єктивно досліджувати феномен Шевченка, деконструюючи міфи, що їх множать перші та другі. Останнього підходу й дотримується у своїй діяльності Національний музей Тараса Шевченка, прагнучи виважено й об'єктивно підходити до вивчення і представлення постаті Тараса Шевченка, а також заповнювати лакуни в його біографії й супутньому історико-культурологічному контексті.

На основі усього вищесказаного сьогодні можна виділити кілька етапів формування рецепції Тараса Шевченка у суспільстві.

Образ народного героя почав формуватися одразу після його смерті й особливо після перепоховання на Чернечій горі у Каневі 22 травня 1861 року, що було приватною ініціативною друзів поета і водночас втіленням його прагнення, яке стало частиною канону: «Як умру, то поховайте мене на могилі серед степу широкого на Вкраїні милій...» (Шевченко 2003, с. 371). У середовищі українських інтелектуалів та серед простих людей Шевченка сприймали в той час як одного з лідерів українського руху, своєрідного батьказасновника, транслятора народної думки та відображення образу народу. Переважно ця рецепція прижилася і закріпилась серед прибічників народництва, в основі ідеології якого була містична віра у селян як носіїв «найвищої життєвої мудрості». Шевченко в цьому контексті сприймався виключно як «людина з народу», своєрідний захисник простих людей від панів (Єфремов 1917, с. 55).

Дещо по-іншому сприймали феномен Тараса Шевченка модерністи, проголосивши своєрідну боротьбу за нього як на найвищий національний авторитет. Вони рішуче протистояли українським народницьким групам, знаходили у творчості поета підтвердження своїм поглядам, робили його «своїм», втиснувши в кліше та шаблони патріархальнопатріотичного дискурсу (Корбич 2014, с. 381). Модерністи актом перечитування Шевченка i, як наслідок, його осучасненням відривали поета від його епохи і переносили в свою. Так створювався романтичний ідеал, на який рівнялися більшість європейських модерністів, коли поступ естетичної свідомості проєктувався на досягнення романтизму, коли світогляд і художні досягнення вітчизняної романтики ставали базовими в конструюванні власного сучасного дискурсу (Корбич 2014, с. 383).

Значний резонанс отримали події, пов'язані з річницею смерті (1911) й народження Тараса Шевченка (1914). Заборона їх відзначення мобілізувала український національний рух і об'єднала суспільство. Комеморативні заходи 1860-1900-х років свідчать про те, що феномен Шевченка став важливим чинником створення всеукраїнського національного простору, певним символом соборності України (Винниченко 1913, с.88-93). 
Основними контекстами, в яких розглядався феномен Шевченка у цій рецепції, були протистояння еліти-народ ${ }^{1}$ і соціальна структура імперського суспільства.

Постать Тараса Шевченка була однією із найпопулярніших в українському суспільстві й усі ідеології у той чи інший спосіб мусили випрацювати власну рецептивну модель Шевченка. Зараз виділяють шість таких моделей: Шевченко комуністичний, націоналістичний, християнський, атеїстичний, дисидентський і анархічний. Серед них найсерйознішою кількісно та найпереконливішою ідеологічно $€$ радянська (комуністична) модель (Альварт 2012).

З 1917 року культ Шевченка бере на озброєння українська влада під час існування незалежної держави, а пізніше - радянська. Його конструювання супроводжується впровадженням офіційного механізму комеморації (збереження пам'яті в суспільстві). В кожному місті чи селі встановлюють пам'ятники, перейменовують вулиці й площі. Клуби і культурні, освітні організації називають на честь Тараса Шевченка. У держустановах відвідувачів зустрічає портрет Кобзаря. Проте Шевченка розглядали у різних контекстах. Для української влади він перш за все став ключовим ідеологом незалежності, свого роду «батьком» державності й ідентичності, оскільки архетип батька як відображення мудрості, розуміння і знання має найбільшу силу переконання і з'являється тоді, коли люди, народ (сини і доньки) потребують допомоги чи авторитетної поради (Єфремов 1917, с. 5-7). Саме таку роль мав виконувати для українського народу Тарас Шевченко, поєднуючи в собі минуле, теперішнє і майбутнє, тобто своєю творчістю продемонструвавши, що було, є і буде, та даючи настанови, як побудувати краще життя. Український національно-визвольний рух активно пропагував та використовував культ Шевченка-пророка як батька народу, як співця свободи, сприймав його заповіді як своєрідну програму національно-політичних перетворень і символ українства (Грушевський 1919,с. 1-2). Ключовим контекстом тут була роль Шевченка у формуванні української державності та його протистояння російській імперській владі. Тобто цю постать розглядали крізь призму політичної історії й протистояння «Україна-Росія», «провінція-центр», а його творчість - як джерело смислів для нової державної ідеології.

Радянський час породжує свою рецепцію Тараса Шевченка. Його вважають «революціонером-демократом», а його біографія слугує наочним прикладом соціальної несправедливості (пекло кріпацтва) і суворого ставлення до інакодумців (арешт і заслання) в Російській імперії. Ця модель включає в себе конфлікт «еліт і народу» ${ }^{2}$, що використовували попередні рецепції, застосовуючи його для зміцнення образу «Шевченка - народного співця», який протистоїть гніту поміщиків у класовій моделі, взятій на озброєння радянською ідеологією. Навчання в Академії мистецтв у Петербурзі й дружбу з російськими художниками та інтелектуалами розглядали як історію братання двох слов'янських народів. «Молодшого» українського брата «старший» російський брат повинен був постійно підтримувати у його розвитку в сферах культури і науки (Альварт 2012). Соціальне походження Шевченка і його переслідування владою дозволяли формувати образ борця з несправедливим царським режимом і захисника селян. У презентації життєпису Шевченка основний акцент був на кріпацькому походженні, а в дорослому віці - на солдатчині. Далі найбільше уваги

\footnotetext{
1 Йдеться про трактування відносин між інтегрованими в імперську систему українськими дворянськими та підприємницькими елітами і «простим народом», що побутувало серед українських інтелектуалів у кінці XIX століття. На їхню думку, еліти забули і відреклися від свого українського походження, сповідуючи інтереси імперії.

2 Радянська інтелектуальна думка дещо модифікувала трактування конфлікту, долучивши до неї класовий підхід. Дворянська еліта - правлячий клас в суспільстві - притісняє «простий народ», виразником ідей якого й був Шевченко.
} 
приділялося соціальним сюжетам у творчості поета - їх зазвичай шифрували терміном «антикріпосницькі». 3 іншого боку, топос боротьби у віршах Шевченка неминуче коментували і трактували через соціальне протистояння, протиставлення вищих і нижчих прошарків суспільства (Савчук 1939, с. 9-10). Радянська влада активно використовувала цей образ у публічному прості й системі освіти, де школи і музеї виконували роль трансляторів офіційного наративу. В 1926 році у Харкові, що тоді був столицею СРСР, був створений Інститут Тараса Шевченка, що мав займатися дослідженням і популяризацією творчості Кобзаря серед широкого загалу. Через 6 років при інституті відкрили Галерею картин Шевченка. ІІї основою стала колекція Василя Тарновського, передана з Чернігова.

Піком радянського трактування образу Тараса Шевченка стала Республіканська виставка його творів, організована до 125-ліття народження у 1939 році. В десяти залах Академії наук УРСР було розміщено понад 900 експонатів. На основі матеріалів цієї виставки було вирішено заснувати постійну експозицію - Центральний музей Тараса Шевченка, який у 1943 році було трансформовано у Державний музей Тараса Шевченка. Основним завданням музею стала трансляція офіційного наративу, пов'язаного з Шевченком, який здебільшого пережив СРСР і перекочував в український національний наратив - образ Шевченка-борця за український народ.

Таким чином, у незалежній Україні пріоритетним став дещо трансформований, проте не переосмислений повністю спосіб прочитання феномена Шевченка. Поет досі залишається борцем проти російського царизму, але вже за незалежність України, за що й постраждав - у нього відібрали свободу і заслали. Долю Тараса Шевченка пропонують вважати символічним каноном шляху страждань, що його довелося пройти українській нації для здобуття незалежності. А сам Шевченко нерозривно ототожнюється з нацією (Альварт 2012).

Без сумніву, Тарас Шевченко залишається національним героєм, а дискусії сьогодні точаться навколо способів комеморації й представлення його феномена у різних соціокультурних контекстах. Творяться нові форми, робляться спроби включення поета до сучасного українського і світового контексту. Шевченко - знакова фігура для всіх політичних сил в Україні, його часто використовують як символ у внутрішньополітичному житті (наприклад, під час подій на Євромайдані (Гранчак, 2014, с. 236-237)). Це один із небагатьох українських діячів, якого хоч сприймають і зображають по-різному, проте майже завжди і в усіх регіонах країни оцінюють позитивно. Зокрема, за результатами опитування, проведеного у вересні 2010 року в рамках проєкту «Україні потрібні герої», Шевченко отримав 97,7\% голосів і став найбільш позитивно оцінюваною історичною постаттю в Україні (Ставлення українців, 2010).

На жаль, не в останню чергу й через заполітизованість, дослідження життя та творчості Тараса Шевченка у своїх методологічних принципах зупинилося на рівні емпіричного збирання даних («відкриття нових фактів») і встановлення правильних дат. Лише нечисленні дослідники (О. Боронь (Боронь 2014; Боронь 2017), Г. Грабович (Грабович 1991; Грабович 2013), М. Назаренко (Назаренко 2017), О. Федорук (Федорук 2013), Р. Харчук (Харчук 2019)) намагаються висвітлити нові проблеми, використовувати сучасні методологічні принципи (зокрема, структуралізм, історію ментальності тощо), однак часто залишаючи поза увагою історичний контекст і суспільство, в якому існував Шевченко. Складається враження, що поет жив окремо, а історична епоха відбувалася окремо. Найбільш недооціненою і проігнорованою $є$ роль соціуму поза радянським класовим підходом. Дослідники майже не торкалися такої проблеми, як вплив міської культури на Тараса Шевченка, представляючи його народним, тобто сільським поетом, продуктом сільської культури і суспільства, й абсолютно відкидаючи освіту, коло спілкування, інтереси. 
Видається, що для дослідників цей контекст має бути одним із основних, адже XIX століття - час бурхливої урбанізації. Зникає середньовічне місто з його укріпленнями, вузькими вулицями і цеховим виробництвом. Місто «розкриває» стіни і дедалі інтенсивніше збільшує свою територію. Тепер у цьому просторі все залежить не від рішення правителя, власника, чиновника, а від людей, їхньої діяльності й мобільності. Місто перетворюється на простір можливостей, де можна змінити соціальний статус, професію, матеріальне становище. Саме міське середовище дало Шевченкові можливість стати тим, ким він став.

Зважаючи на недооціненість і нерозкритість цієї теми, а також на той факт, що без вивчення ролі й впливу міського простору на формування особистості Тараса Шевченка, неможливе об'єктивне вивчення його біографії, творчості й контексту, в рамках якого він формувався, у Національному музеї Тараса Шевченка було прийнято рішення підготувати й реалізувати виставковий дослідницький проєкт «Шевченко мовою міста» (Протокол науковометодичної ради... 2019). Підготовка проєкту тривала майже півтора роки - з літа 2019 року до листопада 2020 року, що пов'язано з необхідністю роботи зі значним об'ємом матеріалів і літератури, а також вивченням фондів інших музейних інституцій, оскільки колекція Національного музею Тараса Шевченка не могла повноцінно проілюструвати сформований наратив. Безпосередньо виставка як тимчасова експозиція відкрилася 03 листопада 2020 року і була відкрита для огляду впродовж трьох місяців - до 01 лютого 2021 року. Окремі напрацювання і блоки пізніше були включені до простору постійної експозиції музею. На думку членів науково-методичної ради музею, ця тема після відповідного дослідження та апробації в ході організації тимчасової експозиції повинна доповнити біографічну частину постійної експозиції в представленні контексту міської культури та її впливу на формування особистості й поглядів Тараса Шевченка. Окрім того, це дасть змогу підкреслити унікальність його долі в контексті можливостей колишнього кріпака у середині XIX століття. Таким чином, основним об'єктом вивчення у рамках проєкту стало місто як простір, що дає людині широкі можливості для роботи, самореалізації, росту і достатку, а також встановлює певні правила співіснування (Концепція виставкового проєкту... 2020, с. 1).

У просторі виставки було вирішено розглянути умовне місто як продукт взаємодії соціально-економічної й соціокультурної складових, відповідно розділивши матеріал на два блоки.

Соціально-економічна модель міста дала змогу продемонструвати, чим економічно воно відрізняється від села і які можливості може запропонувати тим, хто приїздить сюди у часи Шевченка. I хоч ця частина виставкового проєкту пов'язана із постаттю Тараса Шевченка лише хронологічно і контекстуально, вона дозволяє підкреслити його унікальність. Адже потрапивши у місто, він не зупинився на отриманні побутових і соціальних благ, а долучився до створення соціокультурного міського простору. Саме на винятковому прикладі Шевченка у другому блоці, присвяченому соціокультурному простору, ми продемонстрували, що місто неможливе без культурної складової. Тут підкреслено унікальність особистості й долі Тараса Шевченка. Щоб повноцінно реалізуватися як поет та художник, бути актуальним для свого часу й залишити слід в українській історії та культурі, Шевченко повинен був освоїтися в міському просторі й взяти від нього усе, що місто того часу могло йому запропонувати.

Виходячи зі специфіки теми, їі слабкої опрацьованості в науковому дискурсі у зв'язку з Шевченком і необхідності організувати комунікацію з відвідувачами в максимально доступній і зрозумілій формі, було обрано наративну форму презентації виставкового проєкту. В ії рамках наратив (повіствування, оповідь) група кураторів трактує як тип експозиції, що крім експонатів, використовує для представлення історії сценографічну складову, аудіо- та відеоматеріали, тексти, мультимедійні засоби, що були організовані авторами концепції в єдину цілісну оповідь. Тут під наративом мається на увазі спроба 
створення візуальної історіографії, яка в своїй структурі поєднує всі елементи експозиції, мультимедії й архітектури. У зв'язку з цим наративна експозиція не лише створює і веде повіствування в певній послідовності - від початку до кульмінації й завершення, але й повинна запрошувати відвідувача до дискусії й діалогу з темою, експозицією та навколишньою дійсністю (Januszewska 2015.S.56; Ziębińska-Witek 2011. S.263).

Основним наративом виставки було обрано тему міста, того, що воно може дати людині, й що людина може/повинна віддати місту натомість, щоб відбутися в його просторі як особистість. Оповідь будувалася саме навколо міста, його соціокультурного простору, ролі, можливостей, викликів та відповідальності людини в місті, а не навколо особистості Тараса Шевченка (Концепція виставкового проєкту... 2020, с. 1). Перевагу наративній формі презентації було надано тому, що саме наративні музеї й експозиції впродовж останнього десятиліття успішно поєднують колекції артефактів із музейними нематеріальними елементами: спогадами, подіями тощо. А сценарій експозиції грає тут важливішу роль, аніж зібрання «предметів» (Kowal 2019, s. 43). Цей факт був вкрай важливим для кураторської групи, яка поставила собі завдання в першу чергу побудувати зв'язну розповідь, а не продемонструвати якомога більше різноманітних музейних предметів.

У формуванні виставкового простору в першу чергу були враховані особливості концепції, головна наративна лінія, формат викладу матеріалу, наявність чи відсутність оригінальних предметів. Музейні артефакти, макети, репродукції, а також мультимедійні засоби у рамках наративної експозиції потребують належного місця (Mordynski 2015, s. 149). Тому планування такої експозиції було важливим, щоб продемонструвати ії глядачеві не лише як наукову чи науково-популярну розповідь, креативний мистецький проєкт, а й як комплексно сплановане повіствування, наповнене об'єктами, що впливають на відвідувача через певні механізми сприйняття (Mordynski 2015, s. 150). Основними характеристиками наративних експозицій, на думку польських дослідників Д. Ф. Янушевської й П. Коваля, $\epsilon$ використання сучасних методів експонування і нових мультимедійних засобів для опису певного періоду історії чи теми; створення експозиції у вигляді зв'язкої оповіді з власною сценографією; освітня діяльність, побудована навколо наративу експозиції (Kosiewski 2019, s.68). Фактично, наративна експозиція - це розповідь зі своєю зав'язкою, основною частиною і розв'язкою, своєрідний спектакль з ретельно вибудуваною сценографією. Тоді музей стає театром, на сцені якого відбувається передача знань (Januszewska 2015, s. 56). При цьому в просторі наративного музею артефакти та історії актуалізуються, підкреслюються і через такий безпосередній контакт дають змогу відвідувачам краще зрозуміти процеси, частиною яких був той чи інший артефакт або особистість. Інформаційну роль, на думку А. Жембінскої-Вітек, у таких експозиціях відіграють не одиничні предмети, що перебувають в експозиційних залах, а відповідні групи, створені навколо окресленої основи і структуровані відповідно до основної думки виставкової експозиції. Такі експозиції складаються не лише з експонатів, зібраних у групи, але й з архітектурно-пластичної побудови, а також численних допоміжних елементів, як-от карти, плани, креслення, пояснювальні тексти іт. ін. Завдяки усім цим елементам, в тому числі й використанню тексту, експозиція набуває рис певної історичної нарації, де наратив - це оповідь з початком, кульмінацією та закінченням, а експонат - вторинний. Об'єкти представляють минуле, що здається далеким, і матеріалізують ідею минулого, випрацювану суспільством (у процесі дискусій та селекції, коли певні значення будуть виділені, інші - пояснені), щоб підпасти під певну версію історії. В експозиції об'єкти позбавляються своєї багатозначності й інтегруються в конкретну вибрану нарацію (Ziębińska-Witek 2011, s. 68).

Для виставкового проєкту «Шевченко мовою міста» такою нарацією стала розповідь про соціально-економічний і соціокультурний міський простір. Експозиція виставки 
розділена на два відповідні блоки. Блок «Місто як соціально-економічний простір» представляє місто як центр економічного життя, магніти, що притягують людей на роботу, навчання, ринки (ярмарки), відпочинок. Завданням блоку була демонстрація можливостей міста як соціально-економічного простору. Увага була заакцентована на темі можливостей для простих людей, які потрапляють до міста після звільнення з кріпацтва. Також блок містить розповідь про кріпацтво і можливості звільнення з нього - важливого аспекту для розуміння особливостей станового суспільства і того, що місто може запропонувати людям різних станів у часи Тараса Шевченка: які двері відчинити, який кар'єрний ріст і обмеження забезпечити. I що місто попросить натомість - який внесок у його розвиток робили прості люди.

Про це куратори виставки розповіли на прикладі двох братів, збірних вигаданих персонажів, щойно звільнених кріпаків, долі яких сконструйовані на основі реальних прикладів - відомого підприємця Івана Вавилова та одного з винахідників паровоза Єфима Черепанова. Йшлося про те, яку роботу міг отримати колишній кріпак і чи міг він піднятися по соціальній драбині в різних сферах економічної діяльності. Для братів були сконструйовані дві лінії - промисловість, розвиток якої став серйозним фактором у процесі урбанізації, та торгівля як найбільш «міський» вид діяльності. Спеціально для цієї частини експозиції були розроблені мультимедійні програми, за допомогою яких відвідувач на інтерактивній карті міг познайомитися зі структурою й кількістю магазинів і промислових підприємств у Києві XIX століття. Надалі ми плануємо перенести дані матеріали на онлайн-платформу на базі порталу Національного музею Тараса Шевченка, доповнювати і розширювати їх.

Саме ці два напрямки давали можливість простим людям (у рамках нашого наративу двом братам), потрапивши до міста і пройшовши певних шлях, не лише існувати в рамках міського простору, але й отримати освіту, зробити кар'єру і, можливо, навіть зібрати капітал та кардинально змінити соціальний статус своїх дітей. Фактично мова йде про створення нової міської буржуазії після скасування кріпацтва. При цьому куратори проєкту продемонстрували і розповіли, чому для простих людей у той час були закриті інші кар'єрні "двері» можливостей. На цьому фоні виразнішою $€$ непересічна історія Тараса Шевченка, розказана у другому блоці, - він зміг пройти в зачинені для більшості двері, ставши «своїм» і відбувшись у міському просторі. Обидва блоки експозиції об'єднує не лише тема міста, а й тема індивідуальної свободи як основної ідеї міського простору - без неї повноцінно інтегруватися туди неможливо.

Проте місто, як раніше було зазначено, - це не лише економічний простір і можливості для заробітку, а також простір соціокультурний. Розкриттю цієї теми присвячений другий блок експозиції «Місто як соціокультурний простір». Тут акцент було зроблено на темі культурного простору і факторах, які його формують, ролі цього середовища у становленні особистості, зокрема Тараса Шевченка, і розвитку міста. Саме культурний міський простір дає можливість свідомого вибору культурного продукту для споживання. Це в свою чергу впливає на розвиток особистості, вибір місця для навчання, професійну реалізацію і стиль життя, розширює можливості та соціальні контакти. Всі ці фактори визначають, як міський культурний простір впливав і впливає на становлення людини у місті, віднайдення свого місця в ньому, а також на її внесок у функціонування культурного міського середовища.

Завданням блоку було продемонструвати, як міська культура вплинула на Тараса Шевченка, які чинники формували його особистість, смаки, життєвий шлях. Група кураторів проєкту намагалася дати відповіді на запитання, що дав Шевченко містові, який внесок зробив у формування культурного середовища, культурного контенту. Для цього були обрані три універсальні «міські» цінності - свобода, професія, соціальні контакти. 
Для Тараса Шевченка місто стало простором свободи і можливостей: вільне пересування, вибір місця проживання, професії, формування власного стилю життя. Він отримує змогу організовувати побут, обирати культурне дозвілля, налагоджувати контакти, не будучи залежним від традицій чи певного статусу. Місто диктує Шевченкові свої правила поведінки, тож він підлаштовується під специфічний міський ритм і впорядковує свої будні. Щоб стати "своїм» у міському просторі, поет змушений засвоювати культурні та суспільні тренди, вливатися до світських кіл, відвідувати салони, театри, бібліотеки, стати учасником політичного життя. Саме про всі ці форми культурної взаємодії та їх ролі у житті Тараса Шевченка йдеться у цьому блоці експозиції.

Другим важливим фактором становлення особистості Шевченка в місті стала професійна діяльність. Він отримав можливість здобути вищу художню освіту в Академії мистецтв, професію і роботу, перебуваючи у відповідному оточенні. Саме професія художника дала Шевченкові змогу повноцінно ввійти у міський простір, закріпитися в ньому і стати «своїм». Тому тут куратори розповідають історію професійного становлення непересічної особистості в місті. Фундаментальна мистецька освіта, звання вільного художника, новий соціальний статус, саморозвиток, соціальні контакти, робота - усе це Шевченко бере від міста. При цьому він не обмежується наявним каноном і академічною традицією, а намагається створити власний унікальний культурний продукт - як в образотворчому мистецтві, так і в літературі, пропонуючи його містові. Художник виходить за рамка звичного, поєднує академічну манеру зображення з національними темами, формуючи образ української дійсності в образотворчому мистецтві та літературі XIX століття. В рамках цього розділу організатори виставки приділили значну увагу розповсюдженню культурного продукту й усвідомленню Шевченком важливості поширення культури. Тому ми за допомогою освітніх роликів продемонстрували важливу роль офорта й книговидання, доступних лише в міському просторі, для розвитку української літератури та мистецтва, а також для поширення освіти на українських землях у той час. У такий спосіб було підкреслено роль Тараса Шевченка в розвитку і розповсюдженні елементів міської культури XIX століття.

Третім важливим блоком, що демонструє можливості міста, $є$ розділ, присвячений соціальним контактам. Його основний наратив: місто дає людині широке коло спілкування, що впливає на можливості реалізації славних інтересів, і як наслідок - на індивідуальний та професійний розвиток.

Прибувши до міста, Тарас Шевченко намагається освоїтися в цьому просторі через налагодження соціальних контактів. Він потрапляє у середовище петербурзької еліти, 3 інтелектуалами спілкується впродовж життя, елітам адресує свої літературні твори. Завдяки соціальним контактам (нетворкінгу), нехай інколи випадковим, Шевченко отримує свободу, професію художника і можливість "вийти на публіку» як поет - видати «Кобзар». Соціальні контакти, доступні лише в місті, підштовхують його і до активної громадської діяльності: саме в Києві Тарас Шевченко долучається до політичної організації Кирило-Мефодіївське братство, приділяє час просвіті - видає «Букварь Южнорусский», бере участь у діяльності Української громади в Петербурзі.

Проєкт виставки містив доволі масштабну публічну програму, в рамках якої мали відбутися освітні заняття та дискусії на теми, пов'язані з різними аспектами міського життя в минулому і сьогоденні. Зокрема, було заплановане обговорення ролі підприємництва в українських містах, повсякденному житті містян у XIX і XXI століттях, значення національних рухів у житті імперського міста. Одною з ключових мала б бути дискусія про трансформацію образу Тараса Шевченка в міському просторі впродовж XX століття. Проте у зв'язку 3 карантинними обмеженнями через COVID-19 організатори змушені були перенести публічну 
програму в онлайн-режим. Не зважаючи на певні незручності, цей режим відкрив нові можливості для кураторів проєкту. Так, ряд онлайн-лекторіїв та кураторських екскурсій дав можливість охопити не лише традиційно залучену до музейних активностей аудиторію, але й привабити нову. А сам онлайн-продукт - освітні ролики, семінари та дискусії, розміщені в Інтернеті на ресурсах музею та глобальних платформах (YouTube, Facebook) - доступний для широкого кола глядачів значно довше, аніж працювала виставка. Цей спосіб комунікації, на наш погляд, дає додаткові можливості говорити про інклюзивність й продовження життя виставкового проєкту «Шевченко мовою міста», а отже й про можливості для постійної його актуалізації.

\section{Список джерел та літератури}

JANUSZEWSKA, D. F., 2015, Muzeum: fenomeny i problemy, Kraków: Universitas.

KOSIEWSKI, P., 2019, Muzeum i narracja. Kilka uwag. W: Kowal P., Wolska-Pabian K, red., Muzeum i zmiana. Losy muzeow narracyjnych. Warszawa-Krakow: Universitas, 73-86.

KOWAL, P., 2019, Społeczny, cywilizacyjny i polityczny kontekst polskiego boomu muzealnego. Muzeum i zmiana. Losy muzeów narracyjnych. Warszawa, Krakow. 35-59

MORDYNSKI, K., 2015, Percepja wystawy a ksztaltowanie przestrzeni ekspozycyjnej. Muzealnictwo. N 56. 149-158

ZIĘBŃSKA-WITEK, A., 2011, Historia w muzeach. Studium ekspozycji holokaustu. Lublin: Wydawnictwo Uniwersytetu Marii Curie-Skłodowskiej.

АЛЬВАРТ, Є., 2012, Тарас Шевченко у культурі пам'яті та політиці історії сучасної України. Historians. [Online] Available from: http://www.historians.in.ua/index.php/en/istoriya-i-pamyatvazhki-pitannya/240-yenni-alvart-taras-shevchenko-u-kulturi-pamiati-ta-politytsi-istorii-suchasnoiukrainy [Accessed: $30^{\text {th }}$ November 2020].

БОРОНь, О., 2014, Повісті Тараса Шевченка і західноєвропейські літератури: Рецепція та інтертекстуальні зв'язки. Київ: Критика.

БОРОНь, О., 2017, Спадщина Кобзаря Дармограя: джерела, типологія та інтертекст Шевченкових повістей. Київ: Критика.

ВИННИЧЕНКО, В., 1913, Фільозофія і етика Шевченка. Промова в 51 роковини смерти поета. «Дзвін». № 2, 88-93.

ВІВСЯНА, І., 2012, Формування культу Т. Г. Шевченка в українській суспільно-політичній думці другої половини XIX ст. Наукові записки [Кіровоградського державного педагогічного університету імені Володимира Винниченка]. Серія : Історичні науки. Вип. 17. 74-82.

ГРАБОВИЧ, Г., 1991, Шевченко як міфотворець. Семантика символів у творчості тараса Шевченка. Переклад Соломії Павличко. Київ: Радянський письменник.

ГРАБОВИЧ, Г., 2013, Шевченкові «Гайдамаки»: Поема і Критика. Наук. ред. Олесь Федорук. Київ: Критика.

ГРАНЧАК, Т., 2014, Тарас Шевченко у соціокультурних вимірах Майдану. Українська біографрістика Випуск 11. 233-246

ГРУШЕВСЬКИЙ, М., 1919, Шевченківські роковини. Життя Поділля. №68. 1-2

ЄФРЕМОВ, С., 1917, Сон - не сон (3 приводу останніх Шевченкових роковин). ЛнВ. Річник XVIII. Київ. Том 67.

ЄФРЕМОВ, С., 1917, Тарас Шевченко. Життя його та діла. Київ: Друкарня т-ва «Час» КОРБИЧ, Г. 2014, Тарас Шевченко в рецепції ранніх українських модерністів. Slavia Orientalis. №3. 381-390 
НАЗАРЕНКО, М., 2017, Поховання на могилі (Шевченкова біографрія у фольклорі та фейклорі). Вид. друге, випр. і доп. Київ: Критика.

ПРІЦАК, О., 1993, Шевченко - пророк, Київ: Інститут сходознавства ім. А. Кримського НАНУ; Інститут української археографії.

CEMEHКO, М., 1998, Я палю свій Кобзар. У: Євшан М. Критика; Літературознавство; Естетика. Київ.

ФЕДОРУК, О., 2013, Перше видання Шевченкових «Гайдамаків»: Історія книжки. Київ.

ХАРЧУК, Р., 2019, Історична пам'ять Т.Г. Шевченка: спроба реконструкції. Київ: ВЦ «Академія».

ШЕВЧЕНКО, Т., 2003, Зібрання творів: У 6 т. Т. 1: Поезія 1837-1847. Київ.

САВЧУК, М., 1939, Велика шана Кобзарю У: Савчук М. ред. Великий поет-революціонер. Одеса: Одес. держ. ун-т, 9-18

Концепція виставкового проекту «Шевченко і місто». Національний музей Тараса Шевченка. Київ. 2020.

Протокол науково-методичної ради Національного музею Тараса Шевченка №7 від 26.06.2019.

Ставлення українців до діячів культури, історичних та політичних діячів (вересень 2010 року). 2010 [Online] Available from: http://polityka.in.ua/info/456.htm. [Accessed: 30 ${ }^{\text {th }}$ November 2020].

\section{References}

ALVART, Ye., 2012, Taras Shevchenko u kulturi pamiati ta politytsi istorii suchasnoi Ukrainy Historians. [Online] Available from: http://www.historians.in.ua/index.php/en/istoriya-i-pamyatvazhki-pitannya/240-yenni-alvart-taras-shevchenko-u-kulturi-pamiati-ta-politytsi-istorii-suchasnoiukrainy [Accessed: $30^{\text {th }}$ November 2020].

BORON, O., 2014, Povisti Tarasa Shevchenka i zakhidnoievropeiski literatury: Retseptsiia ta intertekstualni zviazky. Kyiv: Krytyka.

BORON, O., 2017, Spadshchyna Kobzaria Darmohraia: dzherela, typolohiia ta intertekst Shevchenkovykh povistei. Kyiv: Krytyka.

FEDORUK, O., 2013, Pershe vydannia Shevchenkovykh «Haidamakiv»: Istoriia knyzhky. Kyiv.

HRABOVYCH, H., 1991, Shevchenko yak mifotvorets. Semantyka symvoliv u tvorchosti Tarasa Shevchenka. Pereklad Solomii Pavlychko. Kyiv: Radianskyi pysmennyk.

HRABOVYCH, H., 2013, Shevchenkovi «Haidamaky»: Poema i Krytyka. Nauk. red. Oles Fedoruk. Kyiv: Krytyka.

HRANCHAK, T., 2014, Taras Shevchenko u sotsiokulturnykh vymirakh Maidanu. Ukrainska biohrafistyka Vypusk 11. 233-246.

HRUSHEVSKYI, M., 1919, Shevchenkivski rokovyny. Zhyttia Podillia. №68. 1-2

JANUSZEWSKA, D. F., 2015. Muzeum: fenomeny i problemy, Kraków: Universitas.

KHARCHUK, R., 2019, Istorychna pamiat T.H. Shevchenka: sproba rekonstruktsii. Kyiv: VTS «Akademiia».

Kontseptsiia vystavkovoho proektu «Shevchenko i misto». Natsionalnyi muzei Tarasa Shevchenka. Kyiv. 2020.

KORBYCH, H. 2014, Taras Shevchenko v retseptsii rannikh ukrainskykh modernistiv. Slavia Orientalis. №3. 381-390

KOSIEWSKI, P., 2019, Muzeum i narracja. Kilka uwag. W: Kowal P., Wolska-Pabian K, red., Muzeum i zmiana. Losy muzeow narracyjnych. Warszawa-Krakow: Universitas, 73-86. 
KOWAL, P., 2019, Społeczny, cywilizacyjny i polityczny kontekst polskiego boomu muzealnego. Muzeum i zmiana. Losy muzeów narracyjnych. Warszawa, Krakow. 35-59.

MORDYNSKI, K., 2015, Percepja wystawy a ksztaltowanie przestrzeni ekspozycyjnej. Muzealnictwo. N 56. 149-158.

NAZARENKO, M., 2017, Pokhovannia na mohyli (Shevchenkova biohrafiia u folklori ta feiklori): Vyd. druhe, vypr. i dop. Kyiv: Krytyka.

PRITSAK, O., 1993, Shevchenko - prorok, Kyiv: Instytut skhodoznavstva im. A. Krymskoho NANU; Instytut ukrainskoi arkheohrafii.

Protokol naukovo-metodychnoi rady Natsionalnoho muzeiu Tarasa Shevchenka №7 vid 26.06.2019.

SAVCHUK, M., 1939, Velyka shana Kobzariu U: Savchuk M. red. Velykyi poet-revoliutsioner. Odesa : Odes. derzh. un-t, 9-18

SEMENKO, M., 1998, Ya paliu svii Kobzar. U: Yevshan M. Krytyka; Literaturoznavstvo; Estetyka. Kyiv.

SHEVCHENKO, T., 2003, Zibrannia tvoriv: U 6 t. T. 1: Poeziia 1837-1847. Kyiv.

Stavlennia ukraintsiv do diiachiv kultury, istorychnykh ta politychnykh diiachiv (veresen 2010 roku). 2010 [Online] Available from: http://polityka.in.ua/info/456.htm. [Accessed: 30 ${ }^{\text {th }}$ November 2020].

VIVSIaNA, I., 2012, Formuvannia kultu T. H. Shevchenka v ukrainskii suspilno-politychnii dumtsi druhoi polovyny XIX st. Naukovi zapysky [Kirovohradskoho derzhavnoho pedahohichnoho universytetu imeni Volodymyra Vynnychenka]. Seriia : Istorychni nauky. Vyp. 17. 74-82.

VYNNYCHENKO, V., 1913, Filozofiia i etyka Shevchenka. Promova v 51 rokovyny smerty poeta. «Dzvin». № 2, 88-93.

YEFREMOV, S., 1917, Son - ne son (Z pryvodu ostannikh Shevchenkovykh rokovyn). LNV. Richnyk XVIII. Kyiv. Tom 67.

YEFREMOV, S., 1917, Taras Shevchenko. Zhyttia yoho ta dila. Kyiv: Drukarnia t-va «Chas»

ZIĘBŃSKA-WITEK, A., 2011, Historia w muzeach. Studium ekspozycji holokaustu. Lublin: Wydawnictwo Uniwersytetu Marii Curie-Skłodowskiej.

\section{Спроба створення нових музейних наративів на прикладі виставкового проекту "Шевченко мовою міста»}

Тарас Шевченко є однією з найбільш досліджуваних та обговорюваних постатей в українському суспільстві. Рецепції та оцінка постаті Шевченка в різні епохи були різними. Часто вони залежали від суспільної ситуації чи переважаючих трендів у гуманітарному дискурсі. Ця рецепція коливалась від дуже позитивної оцінки до критичної. Автори виділяють декілька ключових рецепцій Шевченка в українському суспільному просторі («народний герой», "Батько нації», «Поет револючійний демократ»). На їхню думку в сучасній Україні тривають процеси пошуку нового образу Т. Шевченка. Відбувається витворення нових форм суспільного вшанування (комеморації), в тому числі через музейні виставкові проекти. Автори аналізують значення музейних наративних експозицій та виставок для формування нових суспільних образів на прикладі виставкового проєкту «Шевченко мовою міста», який проходив в Начіональному музеї Тараса Шевченка 34 листопада 2020 по 31 січня 2021 року. Куратори намагалися дослідити, дослідити, як змінювався особистий досвід людини в місті у процесі урбанізації з XIX століття та як міське середовище впливало на формування постаті Тараса Шевченка. Саме у чей час міста XIX столітmі міста остаточно стають просторами, які формують тренди, 
акценти суспільного світового розвитку, що впливає і на Т. Шевченка, оскільки саме у місті він отримує побутову свободу, професію та розширює коло спілкування. Місто дає йому розуміння культури, ї̈ сили і важливості не тільки для споживання та прийняття, але і для творення нових смислів. Такий підхід, на думку авторів, дозволяє краще зрозуміти значення постаті Тараса Шевченка, його включення у сучасний український та світовий контекст.

Ключові слова: Тарас Шевченко, наративна експозиція, комеморація, урбанізація, Національний музей Тараса Шевченка, виставка.

Mykhailo Zubar, PhD, Taras Shevchenko National Museum

Михайло Зубар, кандидат історичних наук Національний музей Тараса Шевченка ORCID ID: 0000-0001-7027-8698

Oleh Mahdych, PhD, Taras Shevchenko National Museum

Олег Магдич, кандидат історичних наук, Начіональний музей Тараса Шевченка

ORCID ID: 0000-0002-1973-4077

Advance Access Published: December, 2021 